\title{
Association of XRCC1 Arg399GIn and RAD51 135 G>C Polymorphisms and Epidemiologic Risk Factors with Colorectal Cancer among Selected Filipinos
}

\author{
Teresa T. Sy-Ortin, MD, ${ }^{1,6}$ Maria Cristina R. Ramos, $\mathrm{PhD}^{1,5,7}$ and Pia Marie S. Albano, $\mathrm{PhD}^{1,5,7}$ \\ ${ }^{1}$ The Graduate School, University of Santo Tomas \\ ${ }^{2}$ Remedios T. Romualdez Medical Foundation, Tacloban City, Leyte \\ ${ }^{3}$ Department of Biochemistry Faculty of Pharmacy, University of Santo Tomas \\ ${ }^{4}$ Mariano Marcos Memorial Hospital and Medical Center, Batac, Ilocos Norte \\ ${ }^{5}$ Research Center for Natural and Applied Sciences, University of Santo Tomas \\ ${ }^{6}$ Benavides Cancer Institute, University of Santo Tomas Hospital \\ ${ }^{7}$ College of Science, University of Santo Tomas
}

Mariel V. Capungcol, RMT,1,2 Gladys I. Bathan, MSc, ${ }^{3}$ Allan L. Fellizar, RMT, ${ }^{1,4}$ Ruth R. Bangaoil, MSc, ${ }^{1,5}$

\begin{abstract}
Objectives. Several studies have demonstrated that genetic variants of certain DNA repair genes such as the RAD51 and XRCC1 increase cancer risk substantially. The results were also observed to be race- and tumor sitespecific. Hence, this study aimed to determine the possible association of XRCC1 Arg399GIn and RAD51 135G>C polymorphisms combined with risk factors of colorectal cancer (CRC) among selected Filipinos.
\end{abstract}

Methods. Genomic DNA isolated from peripheral blood samples of histologically confirmed CRC patients $(n=70)$ and their age- and sex-matched clinically healthy controls $(n=70)$ were analyzed for polymorphisms of XRCC1 and RAD51 genes by polymerase chain reaction.

Results. The genotypic distribution pattern of RAD51 135G>C ( $>>0.05)$ was not significantly different between the CRC cases and controls. Significantly higher incidence $(p=0.016)$ of the XRCC1 GG genotype was noted among the cases ( $n=34,49 \%)$ compared with controls $(n=20,29 \%)$. Individuals carrying the XRCC1 AG genotype have a lower risk of developing $\mathrm{CRC}(\mathrm{OR}=0.42,95 \% \mathrm{Cl}=0.21-0.85)$ than the XRCC1 GG genotype. XRCC1 AG genotype combined with alcohol drinking, smoking, or family history of cancer also showed a lower risk of developing CRC. There was no significant association between the genetic variants of RAD51 135G>C and CRC risk. Carriers of both XRCC1 GG and RAD51 CC genotypes showed a 5x higher risk (OR=5.02; 95\%; $\mathrm{Cl}=1.0429-24.1283)$ compared to those carrying other genotype combinations $(p=0.028)$.

Conclusions. XRCC1 Arg399GIn but not RAD51 135G>C may be associated with CRC development among Filipinos. Individuals who drink alcohol, smoke tobacco and have a family history of cancer have a lower risk of developing CRC when they are also carrying the XRCC1 AG genotype. The findings may have significant implications in designing personalized methods for screening, diagnosing, and treating CRC.

Keywords: XRCC1, RAD51, genetic polymorphisms, colorectal cancer, PCR

\section{INTRODUCTION}

Corresponding author: Gladys Ilagan Bathan, MSc Department of Biochemistry

Faculty of Pharmacy

University of Santo Tomas

Sampaloc Manila, Philippines

Email: gibathan@ust.edu.ph
More than 1.8 million new cases of colorectal cancer (CRC) resulting in 881,000 deaths have been recorded worldwide, making it the third most diagnosed cancer and the second leading cause of cancer-related deaths in $2018 .^{1,2}$ By 2030, CRC is projected to rise by $60 \%$ with over 2.2 million new cases and 1.1 million deaths. ${ }^{3}$ The Global 
Cancer Observatory (GLOBOCAN) ranks CRC as the third most common cause of cancer in the Philippines, with $>15,000$ new cases and $>9,000$ deaths in $2018 .{ }^{4}$

CRC generally starts with transforming a normal colorectal epithelium to a benign adenomatous polyp that may lead to colorectal adenocarcinoma. The latter develops through the stepwise accumulation of multiple genetic and epigenetic anomalies, which then progresses to invasive and metastatic tumors. ${ }^{5,6}$ Genomic instability and the resulting gene alterations are key molecular pathogenic steps that occur early in carcinogenesis. These allow the acquisition of a sufficient number of alterations in tumor suppressor genes and/or activation of oncogenes that transform cells and promote tumor progression. The DNA repair pathways work to inhibit anomalies during DNA replication that may result in malformations or carcinogenesis. However, certain genetic variants of DNA repair genes such as the RAD51 and XRCC1 may substantially increase the risk of cancer in carriers because of biochemical alterations resulting from these polymorphisms. ${ }^{7,8}$

RAD51 plays a central role in the homologous recombination of DNA during double-strand break repair. Its protein product catalyzes strand transfer and mediates homologous pairing for the resynthesis of the damaged region. ${ }^{9-11}$ XRCC1, on the other hand, is one of the most important genes involved in base excision repair (BER) and single-strand break repair processes. Its scaffolding protein product is strongly associated with BER pathway coordination by interacting with most BER short patch pathway components. ${ }^{8,12,13}$ Several studies have shown that single nucleotide polymorphisms (SNPs) of XRCC1 are linked with measurably reduced DNA repair capacity and increased risk of several types of cancers, including CRC. ${ }^{13}$

Studies on the possible association of RAD51 G135C and XRCC1 Arg399Gln with the risk of various cancers have been proven to be race- and tumor site-specific. ${ }^{711-33} R A D 51$ G135C is associated with CRC development among Turkish ${ }^{7}$, Bangladeshi ${ }^{17}$, and ethnic Kashmiri ${ }^{20}$ but not among the Iranians. ${ }^{34} \mathrm{It}$ is also associated with breast cancer development among Saudi females ${ }^{28}$, Chinese ${ }^{35}$, and Filipino ${ }^{36}$ populations but not among the Finnish population. ${ }^{37}$ XRCC1 Arg399Gln is associated with CRC development among Kashmiri ${ }^{38}$, S. Koreans $s^{27}$, Japanese ${ }^{39}$, southwest Iranians ${ }^{40}$ but not among Malaysians ${ }^{41}$, and Mexican cohorts. ${ }^{15}$ Both XRCC1 Arg399Gln and RAD51 G135C have been associated with ovarian cancer among Serbian women. ${ }^{30}$

Therefore, this case-control study aimed to determine the possible association of XRCC1 Arg399Gln and RAD51 $135 \mathrm{G}>\mathrm{C}$ polymorphisms combined with other epidemiologic risk factors like smoking, alcohol drinking, and history of cancer in both immediate and extended family with CRC development among selected Filipino population. The findings may have significant implications in designing personalized methods for screening, diagnosing, and treating CRC.

\section{MATERIALS AND METHODS}

\section{Ethical clearance}

Ethical clearances were secured from the Institutional Review Boards of the University of Santo Tomas Hospital (USTH) in Manila (Protocol Reference Number: IRB2016-12-201-IS) and Mariano Marcos Memorial Hospital and Medical Center (MMMH-MC) in Ilocos Norte (RERC Protocol Number: MMMH-RERC-17-002), Philippines, before the implementation of the study. All the study participants gave their written informed consent.

\section{Study Participants}

Filipino patients, who are not products of interracial marriages of both parents and grandparents, with histologically confirmed colorectal cancer (CRC), aged 18 years old and above, were recruited at USTH from January 2016 to December 2017 and at MMMH-MC from January 2016 to April 2019. The CRC cases were newly diagnosed, receiving treatment, or in remission. They were age- $( \pm 2$ years) and sex-matched with physician-assessed clinically healthy controls who were not suspected of having any type of malignancy and living in the same geographical location as the cases. Clinicopathologic features were retrieved from medical and histopathological records, and CRC risk factors were obtained through personal interviews.

\section{Genotyping}

Genomic DNA was isolated from the study subjects' peripheral blood samples using ReliaPrep ${ }^{\mathrm{TM}}$ Blood gDNA Miniprep System (Promega, USA) following the manufacturer's protocol. Genotyping for XRCC1 was done by polymerase chain reaction with confronting two-pair primers (PCR-CTPP). ${ }^{14,35}$ A total PCR reaction volume of $20 \mu \mathrm{l}$ containing $10 \mu \mathrm{l}$ PCR master mix (Taq DNA polymerase, reaction buffer at $\mathrm{pH} 8.5,400 \mu \mathrm{M} d \mathrm{dTPs}$, and $3 \mathrm{mM} \mathrm{MgCl}$ ), $0.4 \mu \mathrm{l}$ of each primer, $6.4 \mu \mathrm{l}$ nuclease-free water, and $2 \mu \mathrm{l}$ of the template DNA was prepared for XRCC1 SNP analysis. The primers 5'-TCCCTGCGCCGCTGCAGTTTCT-3' (F1), 5'-TGGCGTGTGAGGCCTTACCTCC-3' (R1), 5'-TCGGCGGCTGCCCTCCCA-3' (F2), and 5'-AGCCCTCTGTGACCTCCCAGGC-3' (R2) were used to amplify XRCC1 under the following conditions: initial cycle at $95^{\circ} \mathrm{C}$ for $10 \mathrm{~min} ; 30$ cycles of $95^{\circ} \mathrm{C}$ for $1 \mathrm{~min}$, $66^{\circ} \mathrm{C}$ for $1 \mathrm{~min}$, and $72^{\circ} \mathrm{C}$ for $1 \mathrm{~min}$; and a final extension at $72^{\circ} \mathrm{C}$ for 5 min..$^{14,35}$ All PCR products were separated through electrophoresis using $1 \%$ agarose gel with $\mathrm{SYBR}^{\mathrm{TM}}$ Safe DNA gel stain (Thermo Fisher Scientific, Waltham, USA). The expected fragment sizes were $630,447 \mathrm{bp}(\mathrm{G} / \mathrm{G})$, 630, 447, 222bp (A/G), and 630, 222bp (A/A). ${ }^{14,35}$

RAD51 genotyping was performed by polymerase chain reaction-restriction fragment length polymorphism (PCR-RFLP) ${ }^{25,42,43}$ as described with modification on PCR conditions. A total PCR volume of $20 \mu \mathrm{l}$ containing $10 \mu \mathrm{l}$ PCR master mix, $0.5 \mu$ l of each primer, $7 \mu l$ nuclease-free water, 
and $2 \mu \mathrm{l}$ of the template DNA. RAD51 was amplified using the primers 5'TGGGAACTGCAACTCATCTGG-3' (F) and 5'-GCGCTCCTCTCTCCAGCAG-3' (R). The PCR amplification conditions were as follow: initial cycle at $95^{\circ} \mathrm{C}$ for $3 \mathrm{~min} ; 40 \mathrm{cycles}$ of $95^{\circ} \mathrm{C}$ for $30 \mathrm{sec}, 58.7^{\circ} \mathrm{C}$ for $30 \mathrm{sec}$ and $72^{\circ} \mathrm{C}$ for $30 \mathrm{sec}$; and a final extension at $72^{\circ} \mathrm{C}$ for $5 \mathrm{~min}$. PCR products were then digested using BstN1 (New England BioLabs, Inc, USA) for $60 \mathrm{~min}$ at $60^{\circ} \mathrm{C}$. Digested products were separated in $12 \%$ polyacrylamide gel electrophoresis for 90 mins at 100V. Expected digested products were 157 bp (C/C); 157, 86, 71bp (G/C); and 86, 71bp (G/G).

\section{Statistical Analysis}

Prevalence of XRCC1 Arg399Gln and RAD51 135 $\mathrm{G}>\mathrm{C}$ genotypes along with allele and genotype frequencies were computed using the Hardy-Weinberg equilibrium. Pearson's Chi-square test was used to evaluate the genotype frequencies of both XRCC1 Arg399Gln and RAD51 $135 \mathrm{G}>\mathrm{C}$ between the $\mathrm{CRC}$ cases and controls as well as the TNM (TNM classification system of malignant tumors) staging and tumor grade differences between all the genotypes. When the expected frequencies were less than five, Fisher's exact test was used. For the ordinal variable, the Wilcoxon rank-sum test was utilized. The association between genotypes and CRC risk factors was estimated as crude odds ratio (OR) with 95\% confidence intervals using logistic regression. Statistical analyses were performed using STATA 14 (StataCorp LP, College Station, Texas, USA).

\section{RESULTS}

A total of 140 study participants (70 histologically confirmed CRC cases matched with clinically healthy controls) were included. There were no significant differences between cases and controls regarding their epidemiologic risk factors (Table 1).

The genotypic distribution pattern of XRCC1 Arg399Gln and $R A D 51135 \mathrm{G}>\mathrm{C}$ between cases and controls is shown in Table 2. Higher incidence of the XRCC1 GG genotype was observed among the cases $(n=34,49 \%)$ compared with controls $(n=20,29 \%)$. In contrast, a lower incidence of the AG genotype was observed in cases $(n=36,51 \%)$ compared to controls $(n=50,71 \%)$. Genotypic distribution of RAD51 $135 \mathrm{G}>\mathrm{C}$ was comparable between cases and controls. Individuals carrying the XRCC1 $A G$ genotype showed a significant protective effect against developing CRC $(\mathrm{OR}=0.42,95 \% \mathrm{CI}=0.21-0.85)$. There was no significant association between the genetic variants of $R A D 51135 \mathrm{G}>\mathrm{C}$ and $\mathrm{CRC}$ risk.

Combining the XRCC1 $A G$ genotype with risk factors such as alcohol drinking, smoking, or family history of cancer showed significant protective effect $(p=0.012-0.016)$ against developing CRC (Table 3). However, these risk factors did not increase the risk of developing CRC when carrying the RAD51 GC genotype. The combined effect of the two SNPs on CRC risk was also determined (Table 4). Individuals carrying both XRCC1 $G G$ and RAD51 $C C$ genotypes showed a $5 x$ higher risk $(\mathrm{OR}=5.02 ; 95 \% ; \mathrm{CI}=1.0429-24.1283)$

Table 1. Clinical profile of the CRC cases and control participants

\begin{tabular}{|c|c|c|c|c|c|}
\hline \multirow{2}{*}{ Characteristic } & \multicolumn{2}{|c|}{ Cases } & \multicolumn{2}{|c|}{ Controls } & \multirow{2}{*}{$p$-value* } \\
\hline & $(n=70)$ & (\%) & $(n=70)$ & (\%) & \\
\hline Median age at diagnosis (year) & 56.2 & & & & \\
\hline \multicolumn{6}{|l|}{ Sex } \\
\hline Male & 44 & $63 \%$ & 44 & $63 \%$ & $>0.999$ \\
\hline Female & 26 & $37 \%$ & 26 & $37 \%$ & \\
\hline \multicolumn{6}{|l|}{ Alcohol drinking } \\
\hline Former/current & 37 & $53 \%$ & 36 & $53 \%$ & 0.992 \\
\hline Never & 33 & $47 \%$ & 32 & $47 \%$ & \\
\hline No answer & & & 2 & & \\
\hline \multicolumn{6}{|l|}{ Cigarette smoking } \\
\hline Former/current & 31 & $44 \%$ & 25 & $37 \%$ & 0.368 \\
\hline Never & 39 & $56 \%$ & 43 & $63 \%$ & \\
\hline No answer & & & 2 & & \\
\hline \multicolumn{6}{|c|}{ Family history of cancer (immediate family member) } \\
\hline Yes & 23 & $33 \%$ & 13 & $19 \%$ & 0.066 \\
\hline No & 47 & $67 \%$ & 55 & $81 \%$ & \\
\hline No answer & & & 2 & & \\
\hline \multicolumn{6}{|c|}{ Family history of cancer (extended family member) } \\
\hline Yes & 13 & $19 \%$ & 9 & $13 \%$ & 0.392 \\
\hline No & 57 & $81 \%$ & 59 & $87 \%$ & \\
\hline No answer & & & 2 & & \\
\hline
\end{tabular}


Table 2. Comparison of XRCC1 Arg399GIn and RAD51 135G>C allele and genotype frequencies $(\mathrm{n}=140)$

\begin{tabular}{|c|c|c|c|c|c|c|c|}
\hline & \multirow{2}{*}{ Genotype } & \multicolumn{2}{|c|}{ Cases $(n=70)$} & \multicolumn{2}{|c|}{ Controls $(n=70)$} & \multirow{2}{*}{ OR $(95 \% \mathrm{CI})$} & \multirow{2}{*}{$p$-value* } \\
\hline & & Frequency & $\%$ & Frequency & $\%$ & & \\
\hline \multirow[t]{5}{*}{ XRCC1 Arg399GIn } & GG & 34 & 49 & 20 & 29 & 1.00 (ref) & \\
\hline & $A G$ & 36 & 51 & 50 & 71 & $0.42(0.21-0.85)$ & 0.016 \\
\hline & $\mathrm{AA}$ & 0 & 0 & 0 & 0 & & \\
\hline & Arg allele & 0.74 & & 0.64 & & & \\
\hline & Gln allele & 0.26 & & 0.36 & & & \\
\hline \multirow[t]{5}{*}{ RAD51 135G>C } & $\mathrm{CC}$ & 17 & 24 & 16 & 23 & 1.00 (ref) & \\
\hline & GC & 53 & 76 & 54 & 77 & $0.92(0.42-2.02)$ & 0.842 \\
\hline & GG & 0 & 0 & 0 & 0 & & \\
\hline & C allele & 0.62 & & 0.61 & & & \\
\hline & G allele & 0.38 & & 0.39 & & & \\
\hline
\end{tabular}

${ }^{*}$ Crude odds ratio (OR) with $95 \%$ confidence interval was computed using logistic regression

Table 3. Combined effects of XRCC1 AG $(n=53)$ and RAD51 GC $(n=106)$ genotypes with other risk factors

\begin{tabular}{|c|c|c|c|c|c|c|c|}
\hline \multirow{2}{*}{ Gene } & \multirow{2}{*}{$\mathrm{n}$} & \multicolumn{2}{|c|}{ Cases } & \multicolumn{2}{|c|}{ Controls } & \multirow{2}{*}{ OR $(95 \% \mathrm{CI})$} & \multirow{2}{*}{$p$-value* } \\
\hline & & Frequency & $\%$ & Frequency & $\%$ & & \\
\hline XRCC1 AG with alcohol use & 45 & 20 & 44 & 25 & 56 & $\begin{array}{c}0.41 \\
(0.20-0.83)\end{array}$ & 0.014 \\
\hline XRCC1 AG with smoking & 33 & 16 & 48 & 17 & 52 & $\begin{array}{c}0.41 \\
(0.20-0.84)\end{array}$ & 0.015 \\
\hline $\begin{array}{l}\text { XRCC1 AG with family history } \\
\text { of cancer }\end{array}$ & 29 & 14 & 48 & 15 & 52 & $\begin{array}{c}0.40 \\
(0.19-0.81)\end{array}$ & 0.012 \\
\hline $\begin{array}{l}\text { XRCC1 AG with alcohol use } \\
\text { and smoking }\end{array}$ & 30 & 15 & 50 & 15 & 50 & $\begin{array}{c}0.42 \\
(0.21-0.85) \\
\end{array}$ & 0.016 \\
\hline $\begin{array}{l}\text { XRCC1 AG with alcohol use, smoking, } \\
\text { and family history of cancer }\end{array}$ & 12 & 8 & 67 & 4 & 33 & $\begin{array}{c}0.40 \\
(0.20-0.83) \\
\end{array}$ & 0.014 \\
\hline RAD51 GC with alcohol use & 58 & 29 & 50 & 29 & 50 & $\begin{array}{c}0.88 \\
(0.40-1.95) \\
\end{array}$ & 0.757 \\
\hline RAD51 GC with smoking & 47 & 26 & 55 & 21 & 45 & $\begin{array}{c}0.83 \\
(0.37-1.86) \\
\end{array}$ & 0.660 \\
\hline $\begin{array}{l}\text { RAD51 GC with family history } \\
\text { of cancer }\end{array}$ & 31 & 19 & 39 & 12 & 61 & $\begin{array}{c}0.98 \\
(0.44-2.21)\end{array}$ & 0.964 \\
\hline $\begin{array}{l}\text { RAD51 GC with alcohol use } \\
\text { and smoking }\end{array}$ & 43 & 24 & 56 & 19 & 44 & $\begin{array}{c}0.82 \\
(0.37-1.84)\end{array}$ & 0.639 \\
\hline $\begin{array}{l}\text { RAD51 GC with alcohol use, } \\
\text { smoking, and family history of cancer }\end{array}$ & 14 & 11 & 79 & 3 & 21 & $\begin{array}{c}0.84 \\
(0.40-2.09) \\
\end{array}$ & 0.835 \\
\hline
\end{tabular}

${ }^{*}$ Crude odds ratio (OR) with $95 \%$ confidence interval was computed using logistic regression

compared to those having other genotype combinations analyzed in this study $(p=0.028)$. Lastly, results showed no association of the XRCC1 and RAD51 genotypes with the tumor grade or the TNM stage (Table 5).

\section{DISCUSSION}

This case-control study analyzed the XRCC1 Arg399Gln and $R A D 51135 \mathrm{G}>\mathrm{C}$ polymorphisms to determine their association with CRC development among Filipinos. Results showed that XRCC1 Arg399Gln but not RAD51 $135 \mathrm{G}>\mathrm{C}$ might be associated with CRC development among Filipinos. Furthermore, the combination of XRCC1 GG and RAD51 CC genotypes showed a $5 \mathrm{x}$ higher risk of developing CRC. This showed that there was a synergistic effect when the two genotypes were combined. Their combination may impact the decreased DNA repair activity, thus contributing significantly to the increased risk of developing CRC.

The DNA is subject to continuous attack from both exogenous and endogenous toxins. Still, mammalian cells have developed several mechanisms specific to each type of damage to repair the damaged DNA. ${ }^{28}$ Polymorphic variants of DNA repair genes may influence functional deficiencies in DNA repair processes, leading to increased vulnerability to carcinogenesis. ${ }^{13,29,30,38}$ Defects in the DNA repair system would increase the genome's instability and susceptibility to malignant transformation.

The XRCC1 gene is located on chromosome 19q13.213.3. Its encoded protein acts as a scaffolding protein involved in base-excision repair (BER) and single-strand breaks (SSB). It interacts with PARP1, OGG1, and APE1 to facilitate the BER processes. ${ }^{29}$ Among its more than 300 poly- 
Table 4. Association of combined XRCC1 and RAD51 genotypes with CRC development

\begin{tabular}{ccccc} 
Combined genotypes & Case & Control & OR (95\% CI) & $p$-value* \\
XRCC1 AG + RAD51 GC & 28 & 36 & $0.63(0.3223-1.2299)$ & 0.175 \\
XRCC1 AG + RAD51 CC & 15 & 8 & $0.47(0.1864-1.2012)$ & 0.110 \\
XRCC1 GG + RAD51 GC & 17 & 25 & $1.73(0.8321-3.6053)$ & 0.140 \\
XRCC1 GG + RAD51 CC & 2 & 9 & $5.02(1.0429-24.1283)$ & 0.028 \\
\hline
\end{tabular}

${ }^{*}$ Chi-square test except when the expected frequencies were less than five, wherein Fisher's exact test was used

Table 5. Association of XRCC1 Arg399GIn and RAD51 135G>C genotypes with tumor grade (XRCC1

\begin{tabular}{|c|c|c|c|c|c|c|c|c|c|c|c|}
\hline \multirow{2}{*}{\multicolumn{2}{|c|}{ Genotypes }} & \multicolumn{2}{|c|}{$\begin{array}{l}\text { Poorly- and moderately- } \\
\text { differentiated tumors }\end{array}$} & \multicolumn{2}{|c|}{$\begin{array}{c}\text { Well-differentiated } \\
\text { tumors }\end{array}$} & \multirow[t]{2}{*}{$p$-value* } & \multicolumn{2}{|c|}{ Stage I/II } & \multicolumn{2}{|c|}{ Stage III/IV } & \multirow[t]{2}{*}{$p$-value* } \\
\hline & & $\mathrm{n}$ & $\%$ & $n$ & $\%$ & & $\mathrm{n}$ & $\%$ & $n$ & $\%$ & \\
\hline \multirow[t]{2}{*}{ XRCC1 } & GG & 9 & 38 & 8 & 44 & 0.650 & 8 & 38 & 18 & 47 & 0.492 \\
\hline & AG & 15 & 63 & 10 & 56 & & 13 & 62 & 20 & 53 & \\
\hline \multirow[t]{2}{*}{ RAD51 } & CC & 5 & 21 & 2 & 11 & 0.679 & 4 & 19 & 11 & 29 & 0.403 \\
\hline & GC & 19 & 79 & 16 & 89 & & 17 & 81 & 27 & 71 & \\
\hline
\end{tabular}

${ }^{*}$ Chi-square test except when the expected frequencies were less than five, wherein Fisher's exact test was used

morphisms reported, only three (3) are most widely studied - Arg194Trp, Arg280His, and Arg399Gln. ${ }^{18,41}$ These amino acid substitutions influence the protein-protein interactions between XRCC1 and other BER proteins resulting in altered efficiency, function, and damaged DNA repair capacity leading to genetic instability and carcinogenesis. ${ }^{13,27,28,31,40,44}$ Findings regarding the associations of XRCC1 Arg399Gln with CRC have been inconsistent. It has been associated with CRC among the Kashmiri population ${ }^{38}$, South Koreans $^{27}$, Han Chinese from Jiangsu Province, East China ${ }^{45}$, Japanese ${ }^{39}$, and southwest Iranians. ${ }^{40}$ However, lack of association has been noted in a Malaysian cohort ${ }^{41}$, Han Chinese from the southwest region of $\mathrm{China}^{33}$, and Mexican patients. ${ }^{15}$ The difference in results from the Han Chinese population from two different parts of China has been reported due to differences in the study participants' geographical location and genetic makeup. The Han Chinese subjects of Huang et al. (2015) ${ }^{45}$ were from Jiangsu Province, which is located in the eastern portion of China, while those of Zhang et al. (2014) ${ }^{33}$ were from the southwest part of China. Another could be the method of genotyping analysis used by the two research groups. Huang et al. performed PCR-RFLP ${ }^{45}$ while Zhang et al. used PCR-CTPP. ${ }^{33}$

$R A D 51$ plays a central role in repairing double-strand breaks (DSBs) performed by homologous repair (HR). It is the only protein factor that facilitates the pairing and exchange of DNA strands. The RAD51 gene is located at chromosome $15 \mathrm{q} 14-15$ and is highly polymorphic. $\mathrm{G}$ to $\mathrm{C}$ and $\mathrm{G}$ to $\mathrm{T}$ substitutions at positions 135 and 172 have been depicted as SNPs at the 5' UTR of the RAD51 gene, respectively. Both polymorphisms are found in the regulatory element of the RAD51 promoter and have been suggested to be linked with mRNA stability and expression. ${ }^{46}$ The $R A D 51$ $135 \mathrm{G}>\mathrm{C}$ polymorphism is the most commonly studied in many cancers, and this polymorphism is linked with increased cancer susceptibility because of its less efficient or defective repair capabilities. ${ }^{10} R A D 51$ is also associated with $B R C A 1$ and $B R C A 2$ tumor suppressor gene products, suggesting that a defect in recombination may influence carcinogenesis. ${ }^{10,32}$ In the systematic review and metaanalysis of Oh et al. (2018) ${ }^{47}$, it was pointed out that there is a greater risk of CRC in BRCA1 mutation carriers but not in BRCA2 mutation carriers.

Studies on the association of $R A D 51135 \mathrm{G}>\mathrm{C}$ with $\mathrm{CRC}$ have varied results. This study showed that there is no association between $R A D 51135 \mathrm{G}>\mathrm{C}$ and CRC risk. This is similar to a Polish population study that showed no significant association of $R A D 51135 \mathrm{G}>\mathrm{C}$ with $\mathrm{CRC}$ development. ${ }^{43}$ In contrast, the group of $\mathrm{Krupa}^{15}$ and Romanowicz $z^{25,32}$ observed association of this polymorphism with CRC. This discrepancy could be attributed to the difference in sample $s^{4 i z} e^{43}$ or the specimen analyzed. The group of Romanowicz ${ }^{32}$ utilized colorectal tissue while Mucha and colleagues ${ }^{43}$ used blood. RAD51 135G $>\mathrm{C}$ has also been associated with CRC among the Bangladeshi ${ }^{17}$, Turkish $^{7,19}$, and ethnic Kashmiri ${ }^{20}$ populations.

Besides being associated with CRC, RAD51 135G>C has also been linked with breast cancer development among Saudi females ${ }^{28}$ and prostate cancer among Jordanians. ${ }^{21}$ In the study of Ragudo et al. $(2020)^{36}$, the more common RAD51 G/C genotype was not associated with breast cancer development among Filipinos, while the less common recessive $\mathrm{C} / \mathrm{C}$ genotype was observed to potentially increase the risk. XRCC1 Arg399Gln has been associated with breast cancer among Serbian women ${ }^{22}$ and lung cancer among Chinese. ${ }^{23}$ Both RAD51 135G>C and XRCC1 Arg399Gln have been associated with ovarian cancers among Serbian women. ${ }^{30}$ A meta-analysis on RAD51 135G>C SNPs showed significant association with increased risk of squamous cell carcinoma of the head and neck (SCCHN) 
but not in ovarian cancer, acute leukemia, and CRC. ${ }^{24}$ This is consistent with the present study results regarding the lack of association of RAD51 135G $>\mathrm{C}$ with CRC.

Alcohol consumption, tobacco smoking, and family history of cancer have been reported to increase the risk of CRC development. ${ }^{16,39}$ Alcohol consumption and smoking have been established as rich sources of reactive oxygen species and chemical carcinogens known to damage DNA. ${ }^{27,45}$ Although tobacco smoking has long been known to cause lung cancer; studies show that smoking is also detrimental to the colon and rectum because of its carcinogen content. Regular heavy alcohol consumption is also associated with developing a disproportionate increase of tumors in the distal colon. Combined smoking and alcohol consumption can induce chronic inflammation, further increasing the risk of CRC development. ${ }^{48,49}$ Alcohol can act as a cocarcinogen by enabling absorption of carcinogens or as carcinogen itself by converting acetaldehyde in the lumen of the colon and induce DNA damage. ${ }^{45}$ Results of the study showed that the XRCC1 $A G$ allele has a protective effect even with these risk factors.

Interestingly, the study of Skjelbred et al. (2006) $)^{50}$ also showed a reduced risk of high-risk adenomas (a benign form of colorectal tumor) in persons with the XRCC1 Gln allele. The protective effect of the polymorphism may be due to the reduced DNA repair activity of cells, thus encouraging apoptosis instead of repair. Apoptosis is triggered when DNA breaks are not repaired. ${ }^{51}$

This study's findings showed no correlation of the tumor grade or TNM stage with $R A D 51135 \mathrm{G}>\mathrm{C}$ or XRCC1 Arg399Gln polymorphisms. It may be interesting to include the possible association of polymorphisms in these genes with survival and treatment response in future studies. XRCC1 Arg399Gln has been observed to have no association with survival among Thai CRC patients. ${ }^{16}$

In conclusion, XRCC1 Arg399Gln but not RAD51 $135 \mathrm{G}>\mathrm{C}$ may be associated with CRC development among Filipinos. Individuals who drink alcohol, smoke tobacco, and have family history of cancer have a lower risk of developing CRC when they are also carrying the XRCC1 AG genotype. Despite the small number of study participants, the strict age, sex, and geographical origin-match design add to the reliability of this study's findings. However, it is recommended that future studies should include a larger number of participants and include subjects from other parts of the country to represent the Filipino population accurately. Also, $B R C A 1$ mutation in study participants may be determined since the association of RAD51 with the BRCA genes suggests that its homologous activity is affected. Other genetic polymorphisms associated with CRC development among Filipinos should also be screened and utilize other analytes like formalin-fixed paraffin-embedded (FFPE). Fresh tissues can have significant implications in designing personalized methods for screening, diagnosing, and treating CRC.

\section{Acknowledgments}

We thank the Commission on Higher Education (CHED) of the Philippines through its DiscoveryApplied Research and Extension for Trans/Interdisciplinary Opportunities (DARE TO) Research Grants program and the Research Center for the Natural and Applied Sciences (RCNAS) of the University of Santo Tomas, Philippines, for funding this study.

\section{Statement of Authorship}

All authors participated in the data collection and analysis and approved the final version submitted.

\section{Author Disclosure}

All authors declared no conflicts of interest.

\section{Funding Source}

This paper was funded by CHED DARE TO and UST RCNAS grant.

\section{REFERENCES}

1. Bray F, Ferlay J, Soerjomataram I, Siegel RL, Torre LA, Jemal A. Global Cancer Statistics 2018 : GLOBOCAN Estimates of incidence and mortality worldwide for 36 cancers in 185 countries. CA Cancer J Clin. 2018 Nov;68(6):394-424. doi: 10.3322/caac.21492.

2. Ferlay J, Colombet M, Soerjomataran I, Mathers C, Parkin DM. Estimating the global cancer incidence and mortality in 2018: GLOBOCAN sources and methods. Int J Cancer. 2019 Apr 15;144(8):1941-1953. doi: 10.1002/ijc.31937.

3. Arnold M, Sierra MS, Laversanne M, Soerjomataram I, Jemal A, Bray F. Global patterns and trends in colorectal cancer incidence and mortality Gut. 2017;66(4):683-91.

4. The Global Cancer Observatory - Data Sheet Philippines. International Agency for Research on Cancer. 2020.

5. Nguyen HT, Duong HQ. The molecular characteristics of colorectal cancer: Implications for diagnosis and therapy (review). Oncol Lett. 2018;16(1):9-18.

6. Markowitz SD, Bertagnolli MM. Molecular Basis of Colorectal Cancer. N Engl J Med. 2009;361(25):2449-60.

7. Cetinkunar S, Gok I, Celep RB, Ilhan D, Erdem H, Bilgin BC, et al. The effect of polymorphism in DNA repair genes RAD51 and $\mathrm{XRCC} 2$ in colorectal cancer in Turkish population. Int J Clin Exp Med. 2015;8(2):2649-55.

8. Wang B, Wang D, Huang G, Zhang C, Xu DH, Zhou W. XRCC1 polymorphisms and risk of colorectal cancer: A meta-analysis. Int J Colorectal Dis. 2010;25(3):313-21.

9. Richardson C. RAD51, genomic stability, and tumorigenesis. Cancer Lett. 2005;218(2):127-39.

10. Thacker J. The RAD51 gene family, genetic instability and cancer. Cancer Lett. 2005;219(2):125-35.

11. Nogueira A, Catarino R, Faustino I, Nogueira-Silva C, Figueiredo $\mathrm{T}$, Lombo L, et al. Role of the RAD51 G172T polymorphism in the clinical outcome of cervical cancer patients under concomitant chemoradiotherapy. Gene [Internet]. 2012;504(2):279-83. Available from: http://dx.doi.org/10.1016/j.gene.2012.05.037

12. Yeh CC, Sung FC, Tang R, Chang-Chieh CR, Hsieh LL. Polymorphisms of the XRCC1, XRCC3, and XPD genes, and colorectal cancer risk: A case-control study in Taiwan. BMC Cancer. 2005;5:1-8.

13. Al-harithy RN, Al-ghazzawi WM. Polymorphisms of the deoxyribonucleic acid (DNA) repair gene XRCC1 and risk of colon cancer in Saudi patients. J Med Med Sci. 2011;3(9):282-8. 
14. Hussien YM, Gharib AF, Awad HA, Karam RA, Elsawy WH. Impact of DNA repair genes polymorphism (XPD and XRCC1) on the risk of breast cancer in Egyptian female patients. Mol Biol Rep. 2012;39(2):1895-901.

15. Muñiz-Mendoza R, Ayala-Madrigal ML, Partida-Pérez M, PeregrinaSandoval J, Leal-Ugarte E, Macías-Gómez N, et al. MLH1 and XRCC1 polymorphisms in Mexican patients with colorectal cancer. Genet Mol Res. 2012;11(3):2315-20.

16. Siewchaisakul P, Suwanrungruang K, Poomphakwaen K, Wiangnon $\mathrm{S}$, Promthet S. Lack of association between an XRCC1 gene polymorphism and colorectal cancer survival in Thailand. Asian Pacific J Cancer Prev. 2016;17(4):2055-60.

17. Hridy AU, Shabnaz S, Asaduzzaman MD, Shahriar M, Bhuiyan MA, Islam MS, et al. Genetic variations of RAD51 and XRCC2 genes increase the risk of colorectal cancer in Bangladeshi population. Asian Pacific J Cancer Prev. 2020;21(5):1445-51.

18. Wang W, Li J-L, He X-F, Li A-P, Cai Y-L, Xu N, et al. Association between the RAD51 135 G\&gt; $C$ polymorphism and risk of cancer: A meta-analysis of 19,068 cases and 22,630 controls. Gorlova OY, editor. PLoS One [Internet]. 2013 Sep 9 [cited 2019 Oct 8];8(9):e75153. Available from: https://dx.plos.org/10.1371/journal.pone.0075153

19. Yazici M, Yilmaz U, Yilmaz N, Celik F, Isikoren EG. A case-control study on effects of the ATM, RAD51 and TP73 genetic variants on colorectal cancer risk Turkish J Biochem. 2019;44(6):778-786.

20. Nissar S, Baba SM, Akhtar T, Rasool R, Shah ZA, Syed A. RAD51 G135C gene polymorphism and risk of colorectal cancer in Kashmir. Eur J Cancer Prev. 2014;23:264-8.

21. Al-zoubi M, Al-batayneh KM, Al-trad B, Alorjani M. Polymorphisms of 5'-UTR of rad51 gene in prostate cancer. Ecol Genet. 2018;(August):24-9.

22. Krivokuca AM, Cavic MR, Malisic EJ, Rakobradovic JD, KolarevicIvankovic D, Tomasevic ZI, et al. Polymorphisms in cancer susceptibility genes XRCC1, RAD51 and TP53 and the risk of breast cancer in Serbian women. Int J Biol Markers. 2016;31(3):e258-63.

23. Zhu DQ, Zou Q, Hu CH, Su JL, Zhou GH, Liu P. XRCC1 genetic polymorphism acts a potential biomarker for lung cancer. Tumor Biol. 2015;36(5):3745-50.

24. Cheng D, Shi H, Zhang K, Yi L, Zhen G. RAD51 Gene 135G/C polymorphism and the risk of four types of common cancers: A metaanalysis. Diagn Pathol. 2014;9(1).

25. Krupa R, Sliwinski T, Wisniewska-Jarosinska M, Chojnacki J, Wasylecka M, Dziki L, et al. Polymorphisms in RAD51, XRCC2 and $\mathrm{XRCC} 3$ genes of the homologous recombination repair in colorectal cancer- A case control study. Mol Biol Rep. 2011;38(4):2849-54.

26. Haggar FA, Boushey RP. Colorectal cancer epidemiology : Incidence, mortality, survival, and risk factors. 2009;191-7.

27. Hong YC, Lee KH, Kim WC, Choi SK, Woo ZH, Shin SK, et al. Polymorphisms of XRCC1 gene, alcohol consumption and colorectal cancer. Int J Cancer. 2005;116(3):428-32.

28. Tulbah S, Alabdulkarim H, Alanazi M, Parine NR, Shaik J, Khan Pathan AA, et al. Polymorphisms in RAD51 and their relation with breast cancer in Saudi females. Onco Targets Ther. 2016;9:269-77.

29. Liu J, Zheng B, Li Y, Yuan Y, Xing C. Genetic polymorphisms of DNA repair pathways in sporadic colorectal carcinogenesis. J Cancer. 2019;10(6):1417-33.

30. Malisic EJ, Krivokuca AM, Boljevic IZ, Jankovic RN. Impact of RAD51 G135C and XRCC1 Arg399Gln polymorphisms on ovarian carcinoma risk in Serbian women. Cancer Biomarkers. 2015;15: 685-91.

31. Forat-Yazdi M, Gholi-Nataj M, Neamatzadeh H, Nourbakhsh P, Shaker-Ardakani H. Association of XRCC1 Arg399Gln polymorphism with colorectal cancer risk: A huge meta analysis of 35 studies. Asian Pacific J Cancer Prev. 2015;16(8):3285-91.

32. Romanowicz-Makowska H, Samulak D, Michalska M, Sporny S, Langner E, Dziki A, et al. RAD51 gene polymorphisms and sporadic colorectal cancer risk in Poland. Polish J Pathol. 2012;63(3):193-8.

33. Zhang SH, Wang LA, Li Z, Peng Y, Cun YP, Dai N, et al. APE1 polymorphisms are associated with colorectal cancer susceptibility in Chinese Hans. World J Gastroenterol. 2014;20(26):8700-8.
34. Yazdanpanahi N, Salehi R, Kamali S. RAD51 135G >C polymorphism and risk of sporadic colorectal cancer in Iranian population. J Cancer Res Ther. 2018;14(3):614-8.

35. Luo H, Li Z, Qing Y, Zhang SH, Peng Y, Li Q, et al. Single nucleotide polymorphisms of DNA base-excision repair genes (APE1, OGG1 and XRCC1) associated with breast cancer risk in a Chinese population. Asian Pacific J Cancer Prev. 2014;15(3):1133-40.

36. Ragudo GP, Pureza BS, Rimando DA, Manrique MR, Ortin TS, Notarte KI, et al. RAD51 135G>C single nucleotide polymorphism and risk of breast cancer in selected Filipino cases. Philipp J Sci. 2020;149(4):1209-15.

37. Pelttari LM, Kiiski JI, Ranta S, Vilske S, Blomqvist C, Aittomäki K, et al. RAD51, XRCC3, and XRCC2 mutation screening in Finnish breast cancer families. Springerplus. 2015;4:92. https://doi.org/10.1186/ s40064-015-0880-3.

38. Nissar S, Lone TA, Banday MZ, Rasool R, Chowdri NA, Parray FQ, et al. Arg399Gln polymorphism of XRCC1 gene and risk of colorectal cancer in Kashmir: A Case Control Study. Oncol Lett. 2013;5(3): 959-63.

39. Yin G, Morita M, Ohnaka K, Toyomura K, Hamajima N, Mizoue T, et al. Genetic polymorphisms of XRCC1, alcohol consumption, and the risk of colorectal cancer in Japan. J Epidemiol. 2012;22(1):64-71.

40. Hosseini SM, Mohammadiasl J, Talaiezadeh A, Alidadi R, Bijanzadeh M. Influence of two DNA repair pathway polymorphisms in colorectal cancer risk in Southwest Iran. Asian Pacific J Cancer Prev. 2020;21(7):1919-24.

41. Lau TP, Lian LH, Cheah PL, Looi LM, Roslani AC, Goh KL, et al. Lack of correlation between X-ray repair cross-complementing group 1 gene polymorphisms and the susceptibility to colorectal cancer in a Malaysian cohort. Eur J Cancer Prev. 2017;26(6):506-10.

42. Sobti RC, Kaur S, Sharma VL, Singh SK, Hosseini SA, Kler R. Susceptibility of XPD and RAD51 genetic variants to carcinoma of urinary bladder in north Indian population. DNA Cell Biol. 2012;31(2):199-210.

43. Mucha B, Przybyłowska-Sygut K,Dziki Ł, Dziki A, Sygut A,Majsterek I. Lack of association between the $135 \mathrm{G} / \mathrm{C}$ Rad51 gene polymorphism and the risk of colorectal cancer among Polish population. Pol Prz Chir Polish J Surg. 2012;84(7):358-62.

44. Khan NP, Pandith AA, Yousuf A, Khan NS, Khan MS, Bhat IA, et al. The XRCC1 Arg399Gln gene polymorphism and risk of colorectal cancer: A study in Kashmir. Asian Pacific J Cancer Prev. 2013;14(11):6779-82.

45. Huang Y, Li X, He J, Chen L, Huang H, Liang M, et al. Genetic polymorphisms in XRCC1 genes and colorectal cancer susceptibility. World J Surg Oncol [Internet]. 2015;13(1):1-7. Available from: http:// dx.doi.org/10.1186/s12957-015-0650-2

46. Michalska MM, Samulak D, Romanowicz H, Smolarz B. Single nucleotide polymorphisms (SNPs) of RAD51-G172T and XRCC2$41657 \mathrm{C} / \mathrm{T}$ homologous recombination repair genes and the risk of triple-negative breast cancer in Polish women. Pathol Oncol Res. 2015;21(4):935-40.

47. Oh M, McBride A, Yun S, Bhattacharjee S, Slack M, Martin JR, et al. BRCA1 and BRCA2 gene mutations and colorectal cancer risk: Systematic review and meta-analysis. J Natl Cancer Inst. 2018; 110(11):1178-89.

48. Haggar FA, Boushey RP. Colorectal Cancer Epidemiology: Incidence, mortality, survival, and risk factors. Clin Colon Rectal Surg. 2009;6(212):191-7.

49. Nistal E, Fernández-Fernández N, Vivas S, Olcoz JL. Factors Determining colorectal cancer: The role of the intestinal microbiota. Front Oncol. 2015;5(OCT):1-10.

50. Skjelbred CF, Sæbø M, Wallin H, Nexø BA, Hagen PC, Lothe IMB, et al. Polymorphisms of the XRCCI, XRCC 3 and XPD genes and risk of colorectal adenoma and carcinoma, in a Norwegian cohort: A case control study. BMC Cancer. 2006;6:1-9.

51. Kaina B, Ochs K, Grosch S, Fritz G, Lips J, Tomicic M, et al. BER, MGMT, and MMR in defense against alkylation-induced genotoxicity and apoptosis. Prog Nucleic Acid Res Mol Biol. 2001;68:41-54. 